MPRENSA DA

UNIVERSIDADE

DE COIMBRA

COIMBRA

UNIVERSITY

- PRESS 


\title{
RELATIONSHIPS AND INTERGENERATIONAL SOLIDARITIES - SOCIAL, EDUCATIONAL \\ AND HEALTH CHALLENGES
}

Natália Ramos 20

\begin{abstract}
The issue of intergenerational relationships has been gaining greater and greater relevance within the present national and international contexts. The same is happening at academic/scientific and social levels, bringing up huge challenges to communication and solidarity between the different generations and to the social, educational and health policies for the $21^{\text {st }}$ Century. In the discussions on intergenerationality its relevance stands out, namely in terms of: the conveyance of individual, family and collective memories, and conveyance of values, and in the construction of new individual and group identities and trajectories; the education, communication and well-being of the younger and older generations, for instance of grandparents and grandsons, and in the development of new relationships and forms of intergenerational solidarity within the family and within society at large; the promoting of active aging, health and quality of life for individuals, families and communities; intergenerational social and educational projects aimed the inclusion and empowerment of older generations, lesser stereotypes and prejudice based on age, the promotion of dialogue and socialization between generations, as well as the construction of a society for all ages, where different generations may contribute towards a culture of solidarity, inclusiveness and citizenship.
\end{abstract}

Keywords: Intergenerational relations; Intergenerational family solidarity; Family; Grandparents and grandchildren.

\footnotetext{
20 Universidade Aberta, Portugal

Email: natalia@uab.pt
} 


\section{Introduction}

The problem of relationships and intergenerational solidarities has been gaining an increasing relevance in the current national and international context, as well as in the academic/scientific and social environments, posing vast challenges to society, the family, communication between different generations and the policies of 21 st Century, mainly, social, educational and health policies.

This significance has been present at Portuguese and European levels, in particular, carried out by the organization of numerous activities and some special events, including: the year 2012 as the European Year for Active Aging and Intergenerational Solidarity, the annual commemoration on 29 April as The European Day of Solidarity and Cooperation between Generations, and the celebration on 26 July of International Grandparents' Day.

The historic moment in which we live in is becoming increasingly marked by the technological improvements concerning health care this evidence has been reflected in increased longevity, and consequently brings out more emphasis to the requests and consequences of marital and family interactions between individuals of different generations.

It is a challenge to promote a healthy relationship between people of various ages. This type of interaction is only possible in a context in which the recognition of differences, skills and the importance of such interaction exists. The relationship between the older and younger generations, between grandparents and grandchildren gains special emphasis in this context.

In the current international and national reality, increased longevity, the decline in mortality and birth rates, the aging population, increased migration, the improvement of quality of life and social care health, as well as, new family configurations and the various changes in social, cultural and labour dimensions posed challenges.

For instance, changes in family and behaviours values, gender roles, the intense insertion of women into the labour market, the expansion of education and, the difficulties of young people in the labour market have led to major social and family changes. 
These changes have been contributing to: the verticalization of the families; generational enlargement in which the coexistence of four generations in the same family is frequent, the higher complexity in family and intergenerational relationships; frequent readaptation at individual and family levels, new roles, identities and solidarities within families, the increasing number of elders and the plurality of aging (Singley, 1993; Segalen, 1996; Attias-Donfut, 1995, 1998; Ramos, 2005, 2008, 2012).

Nowadays, especially in the European Union the 21st Century is constituted as the elders and grandparents' century, in which there will be a predomination of the older generations in relation to other age groups.

Data revealed by the World Health Organization estimates that in the year of 2025 there will be one billion two hundred million people over 60 years. Among these, approximately $75 \%$ will live at developing countries, and the age group of people aged 80 or over will be the fastest growing group.

The Aging Index of the United Nations estimates that in 2050, there will be 200 people over 60 years old for each 100 children and young people.

The OCDE (2007) estimates that in 2030, people aged over 65 will increase; observing that one in five people will be 65 or more.

In the European Union it is estimated that in 2020 there will be a hundred million senior citizens, among these, seventeen and twenty-two million will be aged 80 or over. It is also expected that older people, that is, aged 80 or more, will reach $12 \%$ in 2060 , compared to $4 \%$ in 2005 .

Portugal is one of the most aged countries in Europe. In the next 50 years, Portugal will maintain this trend towards population aging: it is estimated that in 2060 about 3 elderly per each youth will reside in the country (National Statistics Institute, NSI, 2009). The forecasts registered by the NIS point that by 2050 about $80 \%$ of its population will be aged and dependent.

The proportion of young people (under 15 years) will be reduced (from $15.3 \%$ in 2008 to $11.9 \%$ in 2060 ), as a percentage of the working age population ( $67.2 \%$ in 2008 to $55.7 \%$ in 2060). The population aged 65 years and older will almost double (from $17.4 \%$ in 2008 to $32.3 \%$ in 2060 ). 
Data showed by the European Social Survey (ESS, 2004) points to some indicators of family dynamics in the European context:

- Germany and United Kingdom are the countries in Europe with the highest percentage of people who live alone (20\%).

- In Spain, there is a percentage of $6.1 \%$ people living by themselves, whereas in Portugal 6.8\% of the population lives alone.

- In Portugal, a percentage of $44.6 \%$ of people living alone are between 60 and 74 years old and $25 \%$ of them are 75 years or older.

As world life expectancy increases, new problems become evident and may be strengthened by the existence of economic, cultural, social and gender inequalities. There is a greater need for availability for the families and the use of health services, a greater number of long-term problems, which frequently require interventions involving high costs and complex technology for adequate care, as well as the increasing number of elderly who need or choose to live in institutions that require formal or informal care.

\section{Active Aging}

Scientific advances have been contributing to human longevity and quality of life of older populations, as well as to new theoretical and interventional approaches on the elderly and aging, highlighting the dimensions of active aging, and this as an open stage to other opportunities, activities and roles.

The World Health Organization defines active aging as a process of optimizing opportunities for health, participation and security, in order to enhance quality of life and well-being throughout aging. It refers to the continuing participation in various activities, particularly, in economic, social, cultural, civic affairs, family members, spiritual, leisure, the maintenance of the roles of informal and formal social support networks (WHO, 2002).

Advances and perspectives in terms of aging and human longevity have favoured the image and attitudes toward older people, their social 
and familiar integration, and their self- esteem and also promote intergenerational relationships.

In the current century, the new elderly (Simões, 2005, 2006) live longer. They have higher education levels, are more active and more productive than those elderly from earlier times and they also differ from the stereotypes about adulthood into old age, which are still numerous.

Indeed, the maintenance of the myths, negative stereotypes, prejudices and mistaken beliefs concerning elderly people (ageism) (Butler, 1980, 1989), both in the family and especially in the social sphere has resulted in discrimination against elderly people affecting their social welfare, as well as, their psychological and economic development. The behaviours, representations and policies concerning the elderly people are also affected. The phenomenon ageism is according to this author, a profound psychosocial disorder, characterized by individual and institutional prejudices against older people, by means of myths, stereotypes, aversion and avoidance, thus contributing to lowering their well-being, reducing their social opportunities, weakening their personal dignity and increasing their social isolation and marginalization.

However, opposing the perspectives and models which emphasize mainly the negative dimension of losses and limitations associated with aging models, many authors suggest the need to take into account the active and healthy aging aimed at recognizing and recovering the numerous capabilities and resources provided by older people and significantly contribute to improving their productive activity, well-being, social and intergenerational relationships.

Thus, some authors speak about successful aging (Rowe \& Kahn, 1999; Crowther, 2002; Parker, 2002; Simões, 2005, 2006; Blazer, 2006), positive aging (Vaillante Mukamal, 2001), productive aging (Butler, 1985, 1989), bealthy aging (Willcox et al., 2007) or active aging (WHO, 2002).

Beyond the emphasis on health promotion, adaptation to change, disease and disability prevention, these aging approaches insist on other important variables for optimizing the aging process:

- The importance for older people of active engagement in life, specifically, the importance of their social involvement and maintenance of 
their social ties to different generations, and also the maintenance of productive activity, whether paid or unpaid, intended to produce goods and services carried out in the family or non-familial contexts, with reference to the younger, for instance:

- the importance of maintaining a high functional level concerning the cognitive and physical planes, programs for cognitive stimulation and multidimensional development;

- the importance of experiencing the retirement according to an opening perspective of gain, rather than vulnerability and risk or loss / untying;

- the importance of spirituality, religiosity, personal sense, commitment and optimism;

- the importance of adequate living conditions (in terms of reform, living conditions, safety, etc...) and overall well-being.

\section{Relationships and Intergenerational Solidarity in Family}

The family is constituted by a social network in which there are features and requirements, included and influenced by a wider system of social interactions extended to the community, society and the formal and informal social networks. It is important to stimulate opportunities for dialogue and communication in the family and also in society in order to promote respect for otherness and also for differences in individual, social, cultural and generational dimensions.

Nowadays, despite the changes not only in family structures but also in social and labour environments, the valorization of individualistic values has been emphasizing independence and autonomy, increasing intolerance for material and physical limitations. These facts may hinder the roles and intergenerational relationships and contribute, for instance, to increased conflict, tension and family violence against the elderly and elderly people who live alone or in nursing homes. These evidences did not eliminate the intergenerational family solidarity, particularly, in care for children or the elderly, support in times of illness or crisis or change (divorce, unemployment, migration, maternity / paternity during adolescence). 
These factors did not eliminate participatory altruism (Moscovici, 2001). Participatory Altruism is an intense participation in common life, a dedication and connection to a community, a group which people are identified with. It's an otherness without Other, in which the Self and the Other are not truly distinct. The Other constitutes the We and links the family members, an altruistic and solidary WE family.

As a consequence, multiple forms and practices of intergenerational solidarity are produced in the family environment, invisible and silent: that is a solidarity, dedication and assistance considered natural, a gift /love (Boltanski, 1990), a duty that is not questioned.

Despite presenting a gradual transfer of functions which are considered the exclusive responsibility of the family to other social agents in the European Union and in the U.S., the majority of care provided to individuals has been given by family members, and the family has continued to represent the privileged place of development, socialization, care, protection and solidarity. For instance, in Portuguese culture it is still considered natural and usual for families to remain responsible for the care of their elderly relatives.

Freire (2003) in his educational and communicational approach highlights some necessary conditions in order to have relationships and dialogue in the act of informal and formal caring:

- Love/compassion: implying a commitment and respect for the other, his/her autonomy and freedom;

- Faith: in the potential of each human being and his/her capacity for growth and changes in different life cycles, through policy dialogue and communication;

- Humility: which implies a willingness to listen and respect the others 'opinions even different views posed by different generations;

- Hope: the possibility of transformation and change in individuals and life situations;

- Critical thinking: recognition of the phenomena complexity and human relationships, rejecting the simplifications and dichotomies and accepting the dynamic and cyclical everyday familiar and generational world. 
Studies have shown (Mestheneso et al., 2005), that the relationship between people based on love and affection, the kind of family relationship and affective commitment which is built over time, is a determining variable for the provision of care and family support to different generations, especially the elderly people, overlapping the "obligation and gift." As this study confirms (Eurofamcare Project) carried out with households who take care of dependent elderly people in six European countries (Germany, Greece, Italy, England, Poland and Sweden), the main reasons for providing care for the elderly are the following: affective ties (57\%); duty (15\%), obligation (13\%), the lack of other choice (3\%).

However, concerning care for the elderly as with children and young people, American and European studies emphasize that despite of presenting a large female predominance, men (fathers, husbands or sons) have been increasingly participating in their care (Boltanski, 1990; Saillant, 1992; Lesemann et al. 1993; Kellerhals et al., 1994; Jani-Le Bris, 1994; Salvage, 1996; Attias-Donfut, 1995, 1998; Barber, 1999; Moreira, 2001; Lavoie, 2000; O'Shea, 2002; Ramos, 1993, 2004, 2008, 2012).

The relationships between the different generations in the family, between grandparents, parents and grandchildren have been solid, currently registering, new alliances and networks of support between generations (Attias-Donfut \& Segalen, 1998; Saillant, 2001; Bengtson et al., 2003; Litwak et al., 2003; Smith, 2004).

The family has not lost its function as a social network and it also discovered other ways of partnership with other formal networks, in which two of their main functions are the socialization of children and support to adults shared in formal networks.

In these new alliances and in the practices related to intergenerational solidarity family which remain active, even though invisible and silenced sometimes, and contrary to widespread belief of its loss, has emerged the role of grandparents in the custody and care of children and care by the elderly in the family. 


\section{Grandparents providing children's care and education}

The role and legality of today's grandparents are reinforced in law and in the family. The grandparent - grandchild relationship has been continuing to take a central place in the imagination and discourse of different generational groups (Ramos, 1995, 2005, 2008, 2012).

Grandparents are the basis for the necessary stability between the imaginary concerning family and the ties of family membership. They have participated on conscious and unconscious levels in the psychic construction of grandchildren and also they have been transmitting cultural and generational psychic, emotional, educational and important stability for grandchildren and their parents.

The practice of the grandparents' role, especially the guardian grandmother is marked by a complex relationship frequently surrounded by pleasure, and physical and relational difficulties. These difficulties may result in anxiety and depression.

It is frequent for grandparents to question their competence to deal with social changes and new demands made by children and grandchildren.

The competence for dealing with both: the real and ideal the dimensions becomes an important means for maintaining physical, mental and relational health of grandparents.

Multiple factors may influence the diversity of grandparent-grandchild relationships, and in their higher or lower involvement, specifically: the psychic structure of the grandparents, family history, forms of the relationships with the children, age, gender, health, social and cultural environment in which they live.

At the present time, it is frequent for grandparents to share their young adult grandchildren's lives producing new modalities, particularly emotional, educational and mutual solidarity, where very often the grandchildren become grandparents and also caregivers and /or carry out mediating functions when generational conflicts occur.

At the present time the relationships between grandparents and grandchildren are more individualized, open and more extended in time. 
At the present time, the majority of children and young people get the chance to be born and live longer in the company of the four living grandparents. They are healthier, better educated, live longer and generally they concentrate more economic power (they enjoy their comfortable retirements, and also get state support, and a part of these assets have been used as material aid to their children and grandchildren), the benefit of having a more individualized support offered by grandparents, since fewer children were being born, the grandparents have fewer grandchildren to take care of or offer support (Attias-Donfut \& Segalen, 1998).

In Portuguese culture grandmothers and grandfathers are mothers and fathers twice.

Being a grandparent gives new identities, new roles and interactions, gives meaning to life and brings out a continuing desire. Being close to their grandchildren, grandparents have a direct influence as parents and also parents of the grandchildren, a fact which has an important influence on educational attitudes and behaviours for their children's parents and educators nowadays.

A study carried out by Wolff (1998) in Germany, emphasized that custody of grandchildren by grandparents, originates multiple forms of reciprocity between the three generations:

- Grandchildren will maintain a privileged relationship with the lifelong grandfather who took care of them;

- Parents whose children were cared for by grandparents maintain closer relations with these when they become older, visiting them an average of ten additional annual visits.

The investigation carried out by Attias-Donfut and Segalen (1998) reveals this solidarity and reciprocity between generations, emphasizing that an investment in the role of grandparents does not decrease the investment in older people. Rather, the investment in the elderly is higher in grandparents who regularly deal with their grandchildren.

These investigations emphasized some evidences: among these, 47\% of grandparents who take care of the children on a weekly basis are also regularly elderly parents, while among those who never take care of their grandchildren, only $27 \%$ are dedicated to taking care of their elders. 
Numerous investigations carried out in different social and cultural contexts of either nationals and migrants, particularly in Portugal, confirm the importance of seniors and grandparents concerning the intergenerational diffusion of the culture, language and habits, as well as, the values and educational practices, revealing that this transmission is also involuntary and unconscious.

Other studies also confirm the kind of education and care that parents had in childhood influence the nature and way how they care for and raise their own children (Kivnick, 1982; Brazelton, 1988; Ramos, 2004, 2005, 2012; Kornhaber, 1996; Castellan, 1998).

There are multiple affective and educational functions developed by grandparents, such as: ensuring continuity and affiliation ties; imparting knowledge; providing care and affection to the child, promoting the child's development; saving the memory and facilitating the transmission of the traditions and the family educational and cultural values.

Investigations carried out in Europe and the U.S; reveal that gender has an influence on the roles of being a grandmother and grandfather. This role is important for both, but especially for women who tend to be more active and participative in order to engage preferentially with emotional aspects of mothering activities, socialization and educational practices and daily care of the grandchildren. Men participate, especially in recreational and leisure activities, concerning studies, work and the grandchildren's future (Ramos, 1993, 1995, 2004, 2008, 2012).

Grandmothers and grandfathers leave dissimilar memories and reminders in children and adults. Grandfathers are remembered by grandchildren and associated with the social history, being described in their work, activities and implications concerning outdoor / public domain.

Meanwhile, the grandmothers are associated to the family history, home, kitchen, clothes, that is, in the private/family domain, a clear division of gender roles (Attias-Donfut \& Segalen, 1998).

Regarding grandparents' expectations, studies carried out in the U.S., in which the future grandparents were the subjects especially emphasize that grandmothers, have high expectations regarding their roles. 
Grandmothers have hope that the new role will bring them great satisfaction, they strongly wish to be useful to their grandchildren, and also be known as tolerant and wise.

On the part of the grandparents, they imagine playing a role of counsellors among parents and health care for the grandchildren (Somary \& Stricker, 1998).

The older generations have been keeping on playing an important role in socialization, education and knowledge transfer to new generations. These functions favour the dialogue and the rapprochement between the generations, contribute to the reduction of prejudice and isolation concerning the elderly, as well as helping promote their self-esteem and well-being, and encouraging affection and solidarity ties between the generations involved.

Intergenerational relationships, mainly those among the older and younger generations, between grandparents and grandchildren in an autochthonous context, especially migratory haves contributed to learning the language and culture of the origin country, strengthening the cultural identity, essentially, the younger generation, acting on integration and academic success, as well as on the social cohesion of the group.

The activities between generations provide a space in which different generations, have respected differences and knowledge and also create a common space of mutual sharing of resources, knowledge and affection, exchange, solidarity and dialogue between older and younger based on the knowledge and experiences of each social actor.

Concerning the transmission of knowledge Dumazedier (2002) highlights three modes, which are important for the development of relationships and intergenerational solidarity:

- knowledge etransmission from older to younger generations has continued to play a role in the transmission of knowledge, particularly in the family;

- knowledge transmission from new generations to older women through practices done not only as self-training but also supported by educational institutions or independent of them, done via new technologies;

- peaceful or conflicted coexistence between the knowledge of yesterday and the knowledge of today, towards coeducation of generations, 
aiming at transmitting knowledge and negotiating the boundaries between the knowledge and skills of yesterday and those from today and fighting against generational ghettos.

Oliveira (1993, 1999) highlights the importance of coeducation of generations and the transmission of knowledge from older to younger, namely, knowledge, which Vitale (2000) names legacy.

According to these authors, the legacy that older generations struggle to transmit to young people can be classified as:

- Legacies of order, which refer to the responsibility, organization, habits and education;

- Legacies of solidarity, which relate to the feelings and values such as love, friendship, sense of justice, collaboration and respect;

- Legacy of faith, which is related to faith, spirituality and religiosity.

The elders and grandparents are links of solid support and solidarity between generations, serving as anchors of culture, tradition, education and affections.

\section{Caring for the Elderly in the Family}

Regarding family solidarity concerning the caring for the elderly, in the older generation the responsibility for this care is generally given to the families, mainly to women. Indeed, despite the increased support for formal care, the majority of care for the elderly continues to be provided by family caregivers, or by informal family support, predominantly in Portugal, where families are the major carers for the elderly (Jani Le Bris, 1994).

This family support is expressed into the provision of multiple emotional, psychological, instrumental, domestic and financial modes of care.

Beyond the cultural values and feelings of love, affection and dedication frequently associated with care, other contextual reasons may influence the provision of family care for the elderly, including: longstanding cohabitation relationship between the caregiver and the person who demands a careful degree of dependence of the elderly, the modality of care, the 
availability / unavailability of caregivers, geographical proximity, public policies, lack of support structures and high financial costs of institutionalization, that is, the households for instance. On the other hand, factors such as geographical distance, limited space, female labour, the economic and employment situation and new family configurations can hinder the provision of home care (Attias-Donfut, 1995; Moreira, 2001).

Consequently such informal family support is multifaceted, unpredictable and not imposed in which multiple factors are involved (Finch \& Mason, 1993).

Contrary to a widespread idea of an early institutionalization of the elderly, abandonment and familiar negligence concerning the preceding generations, some studies reveal evidence of the opposites. Indeed, increased longevity implies a higher dependence. The children and grandchildren need to give increased care for their families, over longer periods when compared to the previous generations, often at great personal and professional costs resulting in consequences for physical and psychic health of the carers (Maheu, 1992; Ryff et al., 1995; Salvage, 1996; Haley et al., 1996; Mac Rae, 1998; Saillant, 2001; O’Shea, 2002).

Studies carried out in Portugal, Italy, Greece, Spain, Denmark and Ireland and Brazil, conclude that informal caregivers, such as family members, express a set of symptoms: excessive fatigue, general fatigue, physical and mental exhaustion, anxiety, stress and depressive symptoms. These caregivers, occasionally, present difficulty in reconciling the demands of care with the available resources, including physical and financial resources, frequently being obliged to reduce leisure, social and professional activities.

Work overload originates high physical and mental stress for caregivers and those who receive care, and there may be circumstances of violence, as well as, physical and psychological problems for the carers (Sousa et al., 2004; Figueiredo, 2007; Sequeira, 2007).

Barber and Pasley (1995) examined a group of investigations carried out in U.S. in the last three decades and concluded the following findings: informal care carried out via families represents about $80 \%$ of the care with elderly with chronic disability, and approximately $30 \%$ of 
women who mainly provide care are daughters who leave their jobs or reduce their professional activity to take care of elderly parents, with $25 \%$ of requests for the nursing home being justified by the death of the informal caregiver.

Studies carried through in EU and U.S. in which elderly stayed with the families, conclude that mainly women, the daughter, the daughter-in-law or elderly's wife who take care, represent the vast majority of all family caregivers of dependent elderly, resulting in a double workload given to women (Jani Le Bris, 1995; Salvage, 1996; O'Shea, 2002).

However, concerning the care for the elderly and the children and young people, American and European studies emphasize that despite the predominance of women, the men, children or parents, are increasingly participating in this care (Ramos, 1993, 2004).

Jani Le Bris (1994) reveals in his studies carried out in the European context, including Portugal, that the primary care for the elderly is provided mainly by daughters and secondary care by the children. This study also shows that the female care corresponds to $75 \%$ and $25 \%$ is male. Caregivers are predominantly female wives, in about $20 \%$ of informal caregivers, as well as, daughters and daughters-in-law who represent approximately $64.3 \%$ of the caregivers. The caregivers are mainly retired men and the women are housewives and working women, with daughters are predominant in this circumstance.

Investigations also evidenced direct or indirect reciprocity, immediate or deferred in time of donation, and the bonds of solidarity across generations this movement of giving and receiving was the foundation of familiar social ties in the precursor approach (Mauss, 1960).

Thus, elderly people who in the past spent time taking care of the preceding generations receive care from their children more frequent than others, as the example of the parents serves as a model for future behaviours of children toward themselves (Attias-Donfut, 1995, 1997, 1998). In this sense, this evidence reveals the presence of indirect reciprocity, in which, what is given to some (parents) is received from others (children), recalling the Portuguese saying: you're a son, you'll be a father, and as you'll do so you'll get. 
The support of family solidarity is composed of affections and exchanges of gifts and reciprocity, negotiation and strategies among family members, rules and relationships which long been established. The obligation and duty towards the ancestors in higher or lower scale are present in speech and practice.

These solidarities are also consciously and unconsciously originated, by a sense of obligation and duty, influenced by the values, norms and customs of the culture and social group in which individuals and families have been living (Singley, 1993; Lesemann et al., 1994; Kellerhals, 1994; Attias-Donfut, 1995, 1997; Salvage, 1996). Studies reveal that families of a lower social level consider that taking care of their families is based on duty, while families of higher levels consider the same fact as a choice (Pitrou, 1995; Attias-Doufut, 1995).

In Portugal moral values were identified in the care of children with their parents and in the care with the elderly. Consequently, when parents were dependent the children assumed the obligation to take them in. When formal support is insufficient or nonexistent, the family develops strategies for sharing the tasks of caring, whether at home for the elderly, or through the process of their movement to the children's home (Hespanha, 1993; Jani Le Bris, 1994).

\section{Final Considerations}

Intergenerationality is important as a social and educational project at the individual, family and society levels with a view to eliminating the exclusion of older generations and the formation of stereotypes and prejudices. Its base is age that is, to promote dialogue, learning and socializing among the various generations and also building a society for all ages, in which different generations may contribute to a culture of solidarity and citizenship, as well as people's well-being.

In order to better deal with an aging population, it is necessary for countries, particularly the decision makers countries and civil society unite efforts to develop the implementation of public policies and programs 
that promote and enhance the education, health, social participation, and intergenerational solidarity protection of citizens at all stages of life.

The development of the positive image of aging and the social rights of older generations, promote the participation of older people in society.

There is a need for social and health policies in the area of aging and intergenerationality tailored according to the needs of families and different generations, taking into account the determinants of health throughout the life cycle, gender issues and social inequalities.

There is a strong need for families and carers to be supported and cared for by a society and a more responsible and caring State, a better balance and coordination between informal and formal care and the development of appropriate public policies in this area.

Educating for aging, as well as, education for respect and solidarity with the generations, particularly with the older, is everyone's responsibility at all social levels.

However, the family is the first example of intergenerational relationship, the first socializing and educational institution and the most responsible for the transmission of culture and values between generations. In this sense, especially in the family, these values have to be truly taught, cultivated and deepened. It is in different contexts and sectors but mainly in the family that active aging and aging with hope can be promoted and nurtured.

At the time I thought, though my grandmother was also a very wise woman, she couldn't rise to the heights my grandfather could, a man who, lying under a fig tree, having his grandson, José at his side, could set the universe in motion just with a couple of words. It was only many years after, when my grandfather had departed from this world and I was a grown man, that I finally came to realize that my grandmother, after all, also believed in dreams. There could have been no other reason why, one evening she was sitting at the door of her poor home where she lived by herself, staring at the biggest and smallest stars overhead, she said these words: "The world is so beautiful and it is such a pity that I have to die (Saramago, 1998). 


\section{References}

Attias-Donfut, C. (1995). Les solidarités entre génerations. Vieillesse, famille, Etat. Paris: Nathan.

Attias-Donfut, C., \& Lapierre, N. (1997). La famille providence. Paris: La Documentation Française.

Attias-Donfut, C. \& Segalen, M. (1998). Grands-parents. La famille à travers les génerations. Paris: Odile Jacob.

Barber, C., \& Pasley, B. (1995). Family care of Alzheimer's patients: the role of gender and generational relationship on caregiver outcomes. Journal of Applied Gerontology, 14(2), 172-121.

Bengtson, V., Lowenstein, A., Putney, N., \&Gans, D. (2003). Global aging and challenges to families. In V. Bengtson \& A. Lowenstein (Eds.), Global aging and challenges to families. New York: Walter de Gruyter.

Blazer, D. (2006).Successful aging. American Journal of Geriatric Psychiatry, 14, 2-5.

Boltanski, L. (1990). L'amour et la justice comme compétences: Trois essais de sociologie de l'action. Paris: Editions Métailié.

Brazelton T. (1988). O desenvolvimento do apego: uma família em formação. Porto Alegre: Artes Médicas.

Butler, R. (1980). Ageism: A foreword. Journal of Social Issues, 36(2), 8-11.

Butler, R. (1985). Productive aging. New York: Springer.

Butler, R. (1989). Dispelling ageism: The cross-cutting intervention. The Annals of the American Academy of Political and Social Science, 503, 138-147.

Castellan, Y. (1998). Les grands-parents ces inconnus. Paris: Bayard Éditions.

Crowther, M., Parker, M., Achenbaum, W., Larimore, W., \& Koenig, H. (2002). Rowe and Kahn's model of successful aging revisited: Positive spirituality - The forgotten factor. The Gerontologist, 42(5), 613-620.

Dumazedier, J. (2002). Penser l'autoformation. Lyon: Chronique Sociale.

Figueiredo, D. (2007). Cuidados familiares ao idoso dependente. Lisboa: Climepsi Editores.

Freire, P. (2003). Pedagogia do Oprimido (36 ${ }^{\mathrm{a}}$ ed.). Rio de Janeiro: Paz e Terra.

Hespanha, M. J. (1993). Para além do Estado - A saúde e a velhice na sociedade-providência. In B. Sousa Santos (Ed.), Portugal, um retrato singular. Porto: Afrontamento.

Jani-LeBris, H. (1994). Responsabilidades familiares pelos dependentes idosos nos países das Comunidades Europeias. Dublin: Fundação Europeia para a Melhoria das Condições de Vida e de Trabalho.

Lesemann, F., \& Martin, C. (1993). Les personnes âgeés: Dépendance, soins et solidarité familiales. Comparaisons Internationales. Paris: La Documentation Française.

Litwak, E., Silverstein, M., \& Bengtson, V. (2003). Theories about families, organizations and social supports. In V. Bengtson \& A. Lowenstein (Ed.), Global aging and challenges to families. New York, Walter de Gruyter.

Mac Era, H. (1998). Managing feelings: Caregiving as emotion work. Research on Aging, 2O(1), 137-160.

Mauss, M. (1960). Essai sur le don. Paris: PUF. 
Mestheneso, E., \& Triantafillou, J. (2005). Overview summary of the Eurofamcare, TransEuropean-Survey Report. Services for Supporting Family Careers of Elderly People in Europe: Characteristics, Coverage and Usage. Athens, Hamburg: Eurofamcare.

Moreira, I. (2001). O doente terminal em contexto familiar: Uma análise da experiência de cuidar vivenciada pela família. Coimbra: SinaisVitais.

Moscovici, S. (2001). Psychologie Sociale des relations à autrui. Paris: Nathan.

OCDE (2007).Trends in severe disability among elderly people: Assessing the evidence in 12 OCDE countries and the future implication. OCDE: Health Working Papers, 26.

Oliveira, P. S. (1993). Vidas compartilhadas: O universo cultural nas relações entre avós e netos. São Paulo: Universidade de São Paulo, Instituto de Psicologia, I.

Oliveira, P. S. (1999). Vidas compartilhadas: Cultura e co-educação de gerações na vida cotidiana.São Paulo: Hucitec/FAPESP.

O’Shea, E. (2002). Améliorer la qualité de vie des personnes âgées en situation de dépendance. (CDCS). Strasbourg: Editions du Conseil de 1`Europe.

Parker, M., Bellis, J., Bishop, P., Harper, M., Allman, R., Moore, M., \& Thompson, P. (2002). A multidisciplinary model of health promotion incorporating spirituality into a successful aging intervention with African American and white elderly groups.The Gerontologist, $42,406-415$.

Pitrou, A. (1995). Le mythe de la famille et du familial. J. C. Kaufmann (Ed.). Faire ou Faire-Faire? Famille et Services. Rennes: Presses Universitaires de Rennes.

Kornhaber, A. (1996). Contemporary grandparenting. New York: Sage Publications.

Ramos, N. (2004). A família nos cuidados à criança e na socialização precoce em Portugal e no Brasil: Uma abordagem intercultural comparativa. In A. Cova, N. Ramos, \& T. Joaquim (Org.), Desafios da comparação: Família, mulher e género em Portugal e no Brasil (pp. 149-190). Oeiras: Celta.

Ramos, N. (2005). Relações e solidariedades intergeracionais na família: Dos avós aos netos. Revista Portuguesa de Pedagogia, 39(1),195-216.

Ramos, N. (2008). Família, cultura e relações intergeracionais. Solidariedade Intergeracional (pp. 315-329). Lisboa: CEMRI, Univ. Aberta.

Ramos, N. (2012). Avós e netos através da(s) imagem(s) e das culturas. In N. Ramos, M. Marujo \& A. Baptista (Ed.), In A voz dos avós: Migração, memória e património cultural (pp. 33-56). Coimbra: Gráfica de Coimbra e Pro Dignitate.

Rowe, J., \& Kahn, R. (1999). Successful aging. New York: Dell Publishing.

Ryff, C., \& Seltzer, M. (1995). Family relations and individual development in adulthood and aging. In R. Blieszne \& V. Hilkevitch (Eds), Handbook of aging and the family. Westport: Greenwood Press.

Saillant, F. (1992). La part des femmes dans les soins de santé. Revue Internationale de l'Action Communautaire, 28(68), 95-106.

Saillant, F., \& Gagnon, E. (2001). Responsabilité pour autrui et dépendance dans la modernité avancée: Le cas d'aide aux proches. Lien Social et Politiques, 46, 55-69.

Salvage, A. (1996). Qui prendra soin d'eux? Perspectives d'avenir de l'aide familiale aux personnes âgées dans l'Union Européenne. Strasbourg: Ed. du Conseil de 1'Europe.

Saramago, J. (1998). Avô Jerónimo e Avó Josefa. Speech given at Swedish Academy on the occasion of Nobel Prize for Literature.Stockholm.

Segalen, M. (1996). Sociologie de la famille. Paris: A. Colin.

Sequeira, C. (2007). Cuidar de idosos dependentes. Coimbra: Quarteto Editora. 
Simões, A. (1985). Estereótipos relacionados com os idosos. Revista Portuguesa de Pedagogia, $X I X, 207-234$.

Simões, A. (2005). Envelhecer bem? Um modelo. Revista Portuguesa de Pedagogia, 39(1), 217-227.

Simões, A. (2006). A nova velbice: Um novo público a educar. Lisboa: Âmbar.

Singly, F. (1993). Sociologie de la famille contemporaine. Paris: Nathan

Somary, K., \& Stricker, G. (1998).Becoming a grandparent: A longitudinal study of expectations and early experiences as a function of sex and lineage. The Gerontologist, 100(1), 53-61.

Sousa, L., Figueiredo, D., \& Cerqueira, M. (2004). Envelhecer em família. Porto: Ambar Editora.

Vaillant, G., \& Mukamal, K. (2001).Successful aging. The American Journal of Psychiatry, 158, 839-847.

Vitale, M. A. (2000). Socialização e família: Uma análise intergeracional. In M. C. Carvalho (Org.). Família contemporânea em debate. São Paulo: Cortez.

Willcox, D., Willcox, B., Sokolovsky, J., \& Sakihara, S. (2007). The cultural context of 'Successful aging' among older women weavers in a northern Okinawan village: The role of productivity activity. Journal of Cross-CulturalGerontology, 22, 137-165.

WHO (2002). Active ageing: A policy framework. Geneva: WHO.

\section{Filmography}

Ramos, N. (1995). Grands-parents et petits-enfants. Le renouveau du Printemps. Betacam, $\mathrm{SP}, \mathrm{c}, 45 \mathrm{mn}$.

Ramos, N. (2001). Acalantos. Gestos e ritmos de embalar em Portugal e no Brasil.Betacam SP, c, $34 \mathrm{mn}$. 